\title{
FMRFamide Modulation of Secretory Machinery Underlying Presynaptic Inhibition of Synaptic Transmission Requires a Pertussis Toxin-Sensitive G-protein
}

\author{
Philip G. Haydon, Helen Man-Son-Hing, Robert T. Doyle, and Mark Zoran \\ Department of Zoology and Genetics, lowa State University Ames, lowa 50011
}

The neuropeptide FMRFamide modulates synaptic transmission between identified neurons of the pond snail Helisoma trivolvis. FMRFamide causes a presynaptic inhibition of transmitter release by actions on ion channels and secretory machinery (Man-Son-Hing et al., 1989). The actions of FMRFamide on secretory machinery were studied using giant synapses that form between somata in culture. Using the calcium cage DM-nitrophen, synchronized, calciumclamped release of neurotransmitter was promoted by UV photolysis. A series of UV flashes (15 msec duration) repeatedly promoted the transient synchronized release of neurotransmitter. Addition of FMRFamide reduced the magnitude of these flash-evoked inhibitory postsynaptic currents. Under conditions of synchronized transmitter release, FMRFamide modulates the secretory responsiveness to internal calcium. The release of neurotransmitter at somasoma synapses was determined to be quantal in nature. To test for the involvement of G-proteins in mediating the effects of FMRFamide on secretory machinery, the modulation of the frequency of miniature inhibitory postsynaptic currents (MIPSCs) was examined. Addition of FMRFamide reduced the frequency of MIPSCs without affecting intracellular free calcium measured with fura-2. Injection of a nonhydrolyzable analog of GTP, GTP $\gamma \mathbf{S}$, mimicked the effect of FMRFamide and reduced MIPSC frequency. Preinjection of the presynaptic soma with the A-protomer of pertussis toxin (PTX) prevented FMRFamide from reducing MIPSC frequency. Thus, a PTX-sensitive G-protein mediates the action of FMRFamide on secretory machinery. Similarly, preinjection of the presynaptic soma with PTX prevented FMRFamide from reducing the magnitude of action potential-evoked IPSC. Dose-response curves for the actions of FMRFamide on secretory machinery and calcium current were constructed and demonstrated that secretory machinery can be modulated at concentrations of FMRFamide $\left(\leq 10_{-7} \mathrm{M}\right)$ that do not affect calcium current magnitude. At a concentration of $10_{-7}$ M FMRFamide, action potential-evoked synaptic transmission was reduced. Thus, synaptic transmission can be reg-

\footnotetext{
Received Mar. 21, 1991; revised July 10, 1991; accepted July 17, 1991.

This work was supported by grants from the National Institutes of Health (NS24233, NS26650) and the Iowa State Biotechnology Council. P.G.H. is an Alfred P. Sloan fellow. We thank Dr. F. Bahls and Trent Basarsky for helpful discussions and for critical comments on an earlier version of the manuscript.

Correspondence should be addressed to Philip G. Haydon, Department of Zoology and Genetics, 339 Science Building II, Iowa State University, Ames, IA 50011

Copyright (C) 1991 Society for Neuroscience $0270-6474 / 91 / 113851-10 \$ 05.00 / 0$
}

ulated by the modulation of secretory machinery, without a requirement for the modulation of ion channels.

The synapse is the primary locus underlying the acquisition and retention of memory. For example, in the marine mollusk, Aplysia, behavioral training that leads to sensitization and associative learning promotes a correlated facilitation of synaptic connections between specific neuron pairs (Castellucci et al., 1970; Hawkins et al., 1983; Kandel et al., 1986). Training that promotes nonassociative behavioral habituation causes a homosynaptic depression of synaptic connections (Castellucci et al., 1970; Kandel et al., 1986). Presynaptic changes that bring about synaptic plasticity can arise at the level of ion channels (Kandel and Schwartz, 1982; Gerschenfeld et al., 1986; Belardetti et al., 1987; Brezina et al., 1987; Brezina, 1988; Lipscombe et al., 1989; Man-Son-Hing et al., 1989) or secretory machinery (Llinas et al., 1985; Man-Son-Hing et al., 1989; Dale and Kandel, 1990; Hackett et al., 1990). The regulation of ion channels alters the calcium influx during the action potential, while the regulation of secretory machinery controls the secretory response to elevated internal calcium.

In cell culture experiments using identified neurons of Helisoma, our studies have demonstrated that the addition of a tetrapeptide, Phe-Met-Arg-Phe- $\mathrm{NH}_{2}$ (FMRFamide), which is endogenous to the nervous system of Helisoma (Bulloch et al., 1988; Richmond et al., 1991), causes a presynaptic inhibition of synaptic transmission (Man-Son-Hing et al., 1989). This presynaptic inhibition is brought about by at least two actions: FMRFamide reduces the presynaptic calcium current to reduce the calcium influx during the action potential and simultaneously reduces the secretory response to calcium (Man-Son-Hing et al., 1989).

There are many subcellular signals that could mediate the actions of FMRFamide on secretory machinery in Helisoma. Man-Son-Hing and Haydon (1990) have shown that FMRFamide acts through a PTX-sensitive G-protein to reduce the presynaptic calcium current and that the activated $\alpha$-subunit of the $\mathrm{G}$-protein $\mathrm{G}_{\mathrm{o} 2}$ has similar actions to FMRFamide's on the calcium current. Studies in non-ncural cells have suggested that G-proteins also regulate secretory apparatus. In mast cells, for example, dialysis with GTP $\gamma$ S under conditions of low internal calcium stimulates rapid exocytosis (Fernandez et al., 1984). The role of G-proteins in regulating neurotransmitter release through actions on secretory apparatus has not been determined. Ngsee et al. (1990) have demonstrated, however, that multiple types of G-proteins, including PTX-sensitive G-proteins, are associated with small synaptic vesicles of the marine ray Dis- 
copyge ommata. The goal of this study was to document quantitatively the action of FMRFamide on secretory apparatus and to determine whether this effect is mediated by a PTX-sensitive G-protein.

We have used a cell culture system of giant synaptic terminals to test for the involvement of G-proteins in regulating secretory apparatus. Identified neurons of Helisoma form chemical synapses between adjacent somata under conditions that prevent neurite extension (Haydon, 1988). The spherical somata permit direct experimental access to presynaptic and postsynaptic elements of chemical synapses and, thus, the ability to microinject pharmacological agents that perturb G-protein activity. Using this system, we demonstrate that FMRFamide acts through a PTX-sensitive G-protein to reduce the secretory response to internal calcium.

Some of these data have appeared in preliminary form (Haydon et al., 1990; Man-Son-Hing and Haydon, 1990).

\section{Materials and Methods}

Cell culture. All experiments were performed on laboratory-reared adult specimens of the albino pond snail Helisoma trivolvis. Buccal ganglia were isolated according to previous techniques (Wong et al., 1981; Haydon et al., 1985) and incubated in $0.2 \%$ trypsin (type III) in defined medium [Dm; 50\% Liebowitz-15 (L-15) with salts for Helisoma] for 30 $\mathrm{min}$ at room temperature. Leibowitz-15 was purchased as a special order $(82-5154 \mathrm{EE}$ ) from GIBCO (Grand Island, NY) that was free of salts and glutamine. At the time of use, L- 15 was diluted to $50 \%$ strength, and salts for Helisoma (in mM: $\mathrm{NaCl}, 40 ; \mathrm{CaCl}_{2}, 4.1 ; \mathrm{KCl}, 1.7 ; \mathrm{MgCl}_{2}$, 1.5; HEPES, 10 ; pH 7.3 with $\mathrm{NaOH})$, L-glutamine $(0.3 \mathrm{mg} / \mathrm{ml})$, and gentamicin $(50 \mu \mathrm{g} / \mathrm{ml})$ were added. After incubation in trypsin, ganglia were pinned to a silicon rubber-based chamber for neuron isolation.

An electrolytically sharpened microknife was used to cut the connective sheath that covers the ganglia. The cut was made adjacent to the visually identified neuron to be isolated. Buccal neurons 5 (B5) and 19 (B19) were removed from their ganglionic environment using suction from a fire-polished macropipette (about $100 \mu \mathrm{m}$ tip diameter) and transferred to Falcon 1008 plastic Petri dishes for culture. Neurons were cultured in $50 \mu \mathrm{l}$ of $10 \%$ freshly collected hemolymph in Dm. Neurons do not adhere to the culture substratum in the presence of hemolymph. In this environment, neurites never extend and somata maintain a spherical geometry (Haydon, 1988; Haydon and Zoran, 1991).

Neuronal somata of B5 and B19 were plated adjacent to one another and made to contact in $10 \%$ hemolymph in Dm. Once contact was made, cells irreversibly adhered to one another for the duration of the culture period. After $1 \mathrm{~d}$ of culture, pairs of somata were transferred to fresh $10 \%$ hemolymph, and by the second day had formed unidirectional cholinergic chemical synapses. On days 2 or 3 , synaptic partners were transferred to poly-L-lysine coated Petri dishes so that they became immobilized for immediate electrophysiological examination. Synaptic partners are devoid of neurites and make contact directly between somata (Haydon, 1988). Neurons were viewed using a Nikon Diaphot inverted microscope. All electrophysiological recordings were made in Dm.

Presynaptic intracellular recordings. Presynaptic neuron B5 was penetrated with glass fiber-fill microelectrodes that were characteristically filled with (in mM) $50 \mathrm{KCl}, 5 \mathrm{EGTA}, 2.56 \mathrm{CaCl}_{2}$, and $10 \mathrm{~K}^{+} \mathrm{HEPES}$ (pH 7.3). When microinjection was required, the tip of the electrode was broken by touching the electrode against a glass coverslip before the onset of recording. To test the pressure injection capacity of each electrode ( $2 \mu \mathrm{m}$ tip diameter), a pressure pulse ( $30 \mathrm{psi}, 50 \mathrm{msec}$ ) was applied to the electrode while viewing the ejection of the electrode filling solution in a droplet of glycerol. Intracellular records were stored on VHS tape using a Unitrade PCM recorder and later transferred to chart paper using a Gould 220 pen recorder. In some experiments, the presynaptic neuron was voltage clamped using a single electrode switched voltage-clamp circuit (Dagan 8800 ).

Postsynaptic voltage clamp. Postsynaptic neuron B19 was voltage clamped in the whole-cell configuration using a patch pipette with a DC resistance of 1-4 M , which was connected to an Axopatch $1 \mathrm{C}$ patchclamp amplifier (Axon Instruments, Burlingame, CA). The pipette so- lution of postsynaptic neuron (B19) contained (in mM) $50 \mathrm{KCl}, 5 \mathrm{MgCl}_{2}$, 5 EGTA, and $5 \mathrm{~K}^{+}$HEPES at $\mathrm{pH}$ 7.3. The release of acetylcholine (ACh) from neuron B5 activates chloride channels that normally cause an inhibitory postsynaptic potential in $\mathrm{B} 19$. By using $50 \mathrm{mM} \mathrm{KCl}$ in the postsynaptic patch solution and holding $\mathrm{B} 19$ at $-80 \mathrm{mV}$, synaptic currents became inward currents that were readily detected above the noise level of postsynaptic recordings (Zucker and Haydon, 1988; Man-SonHing et al., 1989).

Presynaptic calcium clamp. Our previous calcium-clamp experiments utilized the photosensitive calcium cage nitr-5 (Man-Son-Hing et al., 1989). However, due to toxicity associated with long-term use of nitr-5 (P. G. Haydon, unpublished observations) we used the calcium cage DM-nitrophen (Kaplan and Ellis-Davies, 1988) in the present study. In preliminary experiments, we determined that DM-nitrophen has no detectable toxic effects for at least $\mathrm{l} \mathrm{hr}$ following injection into the presynaptic cytosol. The calcium-clamp solution for microinjection contained (in mM) 75 DM-nitrophen, $22 \mathrm{CaCl}_{2}, 1$ fluo-3, and $10 \mathrm{HEPES}$, pH 7.3 .

After microinjection of the DM-nitrophen/Ca solution, the synchronized release of neurotransmitter was promoted using a $15 \mathrm{msec}$ flash of UV light (UG11 excitation filter, Omega Optical), which was delivered from a $75 \mathrm{~W}$ mercury vapor lamp through an epifluorescence $40 \times$ oil immersion objective (Nikon) of a Nikon Diaphot inverted microscope. Delaney and Zucker (1990) and Zoran et al. (1991) have previously shown that flash photolysis of calcium-loaded DM-nitrophen promotes calcium-dependent transmitter release. Fluo-3 was included in the injection solution so that DM-nitrophen injection could be visually monitored and to confirm qualitatively that photolysis elevated internal calcium. Fluo-3 was excited at $485 \mathrm{~nm}(22 \mathrm{~nm}$ band pass), and the emission signal was collected using a $510 \mathrm{~nm}$ long-pass filter. A dichroic mirror that efficiently reflected light at $\mathrm{UV}$ and $485 \mathrm{~nm}$ but transmits fluorescence emission at $>500 \mathrm{~nm}$ (Omega Optical) was used in these experiments since it permits both UV photolysis and the excitation of fluo-3 (Kao et al., 1989).

Quantal analysis of synaptic currents. To determine whether action potential-evoked synaptic transmission is quantal in nature, we compared the magnitudes of spontaneous and evoked IPSCs. Transmitter release was reduced by elevating the concentration of $\mathrm{Mg}^{2+}$ in the bathing medium from the standard $1.5 \mathrm{~mm}$ until failures in synaptic transmission were detected. Elevated $\mathrm{Mg}^{2+}$ concentration varied between preparations but was in the range of 5-20 mM. The magnitude of spontaneous miniature inhibitory postsynaptic currents (MIPSCs) was unaffected by alterations in extracellular $\mathrm{Mg}^{2+}$ concentration. Assuming quantal release of neurotransmitter, the elevation of extracellular $\mathbf{M g}^{2+}$ will reduce the number of quanta released by action potentials until evoked IPSCs are largely due to one quantum. Since MIPSCs arise from only one neuron under these cell culture conditions, we asked whether evoked IPSCs could be fit by a Gaussian distribution with a mean and standard deviation measured from spontaneous MIPSCs in the same preparation. In some cases, multiple Gaussian distributions were fit to the evoked IPSC data using means and standard deviations corresponding to onefold, twofold, and threefold the values obtained for the unitary MIPSCs. Analysis of events was performed using PCLAMP software (Axon Instrumen(s). The heights of Gaussian distributions for evoked IPSCs were estimated using Poisson statistics.

Presynaptic injections. To test for G-protein involvement in mediating the actions of FMRFamide on secretory machinery, guanine nucleotides were microinjected into the presynaptic soma. GTP and GTP $\gamma \mathrm{S}(2 \mathrm{~mm})$ were injected into the presynaptic cell in a standard internal saline consisting of (in mM) $50 \mathrm{KCl}, 2.56 \mathrm{CaCl}_{2}, 5$ EGTA, and $10 \mathrm{~K}^{+} \mathrm{HEPES}$ (pH 7.3). Characteristically, nucleotides were injected using three to five $50 \mathrm{msec}$ pulses of $30 \mathrm{psi}$ pressure that was controlled by a Narashige IM-200 pressure injection system. The final nucleotide concentrations were estimated in separate experiments by measuring the fluorescent emission intensity of the dye fluorescein that had been injected into neuron B5. We estimate that following microinjection, nucleotides were diluted to a final concentration of $13 \mu \mathrm{M}$.

To begin to identify the class of G-protein that mediates FMRFamide's actions, the A-protomer of pertussis toxin (PTX) was injected into neuron B5 for between $20 \mathrm{~min}$ and $4 \mathrm{hr}$ before testing the effect of FMRFamide. Similar observations were obtained independent of the duration of PTX incubation in neurons. PTX $(0.2 \mu \mathrm{g} / \mu \mathrm{l})$ was stored in $40 \mathrm{~mm}$ dithiothreitol (DTT) in the standard internal solution. Immediately before microinjection, PTX was mixed with an equal volume of $40 \mathrm{~mm} \mathrm{NAD}^{+}$and $10 \mathrm{~mm} \mathrm{ATP} \mathrm{in} \mathrm{internal} \mathrm{saline} \mathrm{to} \mathrm{yield} \mathrm{a} \mathrm{solution}$ 
containing $0.1 \mu \mathrm{g} / \mu \mathrm{l}$ PTX, $20 \mathrm{~mm}$ DTT, $20 \mathrm{~mm} \mathrm{NAD}^{+}$, and $5 \mathrm{~mm} \mathrm{ATP}$. We standardly coinject nicotinamide adenine dinucleotide $\left(\mathrm{NAD}^{+}\right)$and ATP with PTX to permit effective ADP-ribosylation of G-proteins.

Measurement of MIPSC frequency. MIPSCs were counted in $1 \mathrm{~min}$ time bins to obtain measurements of MIPSC frequency. Action potentials in the presynaptic cell were prevented by injecting constant, hyperpolarizing current into B5 to bring the membrane potential of this cell just below threshold for spikes. Characteristically, a 5 min control period of secretory activity was monitored before FMRFamide $\left(10^{-9}\right.$ $\mathbf{M}$ to $10^{-5} \mathbf{M}$ ) was added to the bathing medium. Neurons were exposed to FMRFamide for $6 \mathrm{~min}$ and were washed with $30 \mathrm{ml}$ of Dm (recording chamber volume $=1 \mathrm{ml}$ ) and allowed $6 \mathrm{~min}$ for recovery. The average MIPSC frequency was determined during minutes 5 and 6 of FMRFamide exposure or of recovery for comparison to the average frequency during the 5 min pretest period. When a dose-response curve was constructed, synapses were excluded from analysis if the frequency of MIPSCs did not return to within $\pm 25 \%$ of the pretest value.

Estimation of intracellular free calcium. To determine whether FMRFamide affected the internal free calcium level of the presynaptic neuron in the absence of the calcium cage DM-nitrophen, cells were loaded with the fluorescent calcium indicator fura-2 (Grynkiewicz et al., 1985). The soma-soma synapse was incubated for $1.5 \mathrm{hr}$ in $5 \mu \mathrm{M}$ fura-acetoxymethyl ester (fura $2 / \mathrm{AM}$ ) at room temperature followed by incubation for a period of $>2 \mathrm{hr}$ in $\mathrm{Dm}$ for deesterification of the indicator. Fura-2-loaded neurons B5 and B19 were transferred from their culture dishes onto polylysine-coated glass coverslips attached to the underside of a Falcon 1008 Petri dish, in which a $1 \mathrm{~cm}$ diameter hole had been drilled in the base.

Fura-2 was excited with UV light alternating between 340 and 380 $\mathrm{nm}$. Fluorescent emission $(510 \mathrm{~nm})$ was recorded with a photomultiplier tube, and the emission intensities at excitation wavelengths of 340 (10 $\mathrm{nm}$ band pass) and $380 \mathrm{~nm}$ ( $13 \mathrm{~nm}$ band pass) were recorded using the UMANS system (Chester M. Regen, Urbana, IL). Quantitation of estimated internal free calcium was performed using the ratiometric method according to Cohan et al. (1987).

Calcium current. Whole-cell recordings of macroscopic calcium currents in presynaptic membrane were made according to techniques described by Haydon and Man-Son-Hing (1988) and Man-Son-Hing et al. (1989). Patch pipettes (1-2 M $\Omega$ DC resistance) were filled with an internal solution that contained (in mM) $35 \mathrm{CsCl}, 5 \mathrm{MgCl}_{2}, 5$ EGTA, 5 HEPES, and 1 GTP (Tris salt) (pH 7.3 with $\mathrm{CsOH})$. The internal solution usually contained $5 \mathrm{~mm}$ ATP $\left(\mathrm{Na}^{+}\right.$salt); similar results were obtained with or without ATP. Spherical somata were bathed in an external saline that contained (in $\mathrm{mM}$ ) $0 \mathrm{NaCl}, 4.1 \mathrm{CaCl}_{2}, 1.5 \mathrm{MgCl}_{2}, 1.7 \mathrm{KCl}, 30$ tetraethylammonium (TEA) $\mathrm{Br}, 10$ 4-aminopyridine, 10 HEPES, and 30 sucrose (pH 7.3 with TEA OH). These solutions effectively block $\mathrm{Na}^{+}$and $\mathrm{K}^{+}$currents. Neurons were depolarized from a holding potential of $-60 \mathrm{mV}$ to depolarized command potentials of -50 to $+50 \mathrm{mV}$. Unfortunately, it is not possible to monitor transmitter release and the presynaptic calcium current since the conditions required for ideal study of the calcium current block synaptic transmission.

When neuron B5 is plated in nonadhesive culture and retains a spherical geometry, it loses its low-voltage-activated calcium current but selectively maintains a high-voltage-activated (HVA) calcium current. The somatic HVA calcium current is electrophysiologically and pharmacologically similar to the calcium current of growth cones of neuron B5 (Haydon, 1988).

Chemicals. GTP was obtained from Sigma (St. Louis, MO), GTP $\gamma$ S from Boehringer Mannheim Biochemicals (Indianapolis, IN), fura-2/AM from Molecular Probes (Eugene, OR), pertussis toxin (A-protomer) from List Biological Labs (Campbell GA), FMRFamide from Bachem (Philadelphia, PA), and DM-nitrophen from Calbiochem (La Jolla, CA).

All data are presented as means \pm SEM unless otherwise stated. Statistical tests of significance were performed using the Student's $t$ test.

\section{Results}

\section{Calcium-clamped, synchronized synaptic transmission}

Our previous studies of secretory machinery were performed by analyzing the frequency of asynchronous MIPSCs under calcium clamp. Our assumption in such experiments was that the modulation of MIPSC frequency was indicative of a modulation of the amount of transmitter released under synchronous release conditions during the action potential. Delaney and Zucker (1990) demonstrated that the calcium cage DM-nitrophen (Kaplan and Ellis-Davies, 1988) can be effectively used to promote the synchronized release of transmitter from the squid giant synapse. We have injected DM-nitrophen into the presynaptic soma of Helisoma giant synapses and demonstrated that this calcium cage can also promote synchronized transmitter release at this synapse.

DM-nitrophen was microinjected, together with fluo-3 into the presynaptic cell body. Fluo-3 was used to demonstrate that DM-nitrophen was successfully injected into the synapse and that photolysis caused an increase in intracellular free $\mathrm{Ca}^{2+}$. No quantitative estimates of free calcium levels were made with fluo-3. Flash photolysis $(15 \mathrm{msec})$ reliably promoted the synchronized release of neurotransmitter from this synpase (Fig. $1 A$ ). The amplitude of the flash-evoked IPSC was dependent on both the duration and intensity of UV photolysis. When UV flashes shorter than $15 \mathrm{msec}$ duration were applied to preparations, the magnitude of the synchronized IPSCs was reduced. However, flash-to-flash variability in IPSC magnitude was considerably increased. With $15 \mathrm{msec}$ duration UV flashes, the flash-evoked IPSC was characteristically much larger than the spike-evoked IPSC (Fig. 1A,B; note the different calibration values). The time course of the flash-evoked synchronized IPSC was very similar to the IPSC evoked in response to an action potential (Fig. 1C).

Consecutive UV flashes promoted the release of neurotransmitter (Fig. 1D). However, in general each successive IPSC had a smaller amplitude. The amount of rundown of flash-evoked synaptic transmission was variable between preparations. For this reason, we performed preliminary experiments to determine this variability. The decrease in flash-evoked IPSC amplitude from the first to the second flash was determined. In 11 preparations, the magnitude of the second IPSC decreased to 0.78 \pm 0.55 (mean $\pm \mathrm{SD}$ ) of the first. This considerable variability is likely due to true biological intersynaptic variability and to different amounts of loading with DM-nitrophen. Having obtained this estimate of the variability between synapses, preparations were excluded from analysis in subsequent experiments if the amplitude of the second flash-evoked IPSC fell outside of the range $0.23-1.33$ (one SD around the mean) or if flash photolysis failed to evoke an IPSC in the washout period. Action potential-evoked IPSCs do not exhibit this rundown, which may represent the depletion of the readily releasable pool of transmitter under conditions of high transmitter output during flash photolysis.

\section{FMRFamide modulation of calcium-clamped, synchronized synaptic transmission}

To test the effect of FMRFamide on synaptic transmission, pairs of UV flashes ( $2 \mathrm{~min}$ flash interval) were provided in three groups (period 1, pretest; period 2, test; and period 3, washout; Fig. 1D). Each experimental period was separated by $5 \mathrm{~min}$. The mean magnitudes of IPSCs in each of the threc groups wcre normalized to the mean IPSC size measured in the pretest period. Because of rundown, the normalized value of the IPSC in the test (flashes 3 and 4) and washout periods (flashes 5 and 6) of experimental preparations (exposed to FMRFamide during test period) were statistically compared to the values obtained in parallel experiments using control preparations.

The addition of $10^{-6} \mathrm{M}$ FMRFamide during the test period reduced the magnitude of the flash-evoked IPSC. Figure 2 shows 


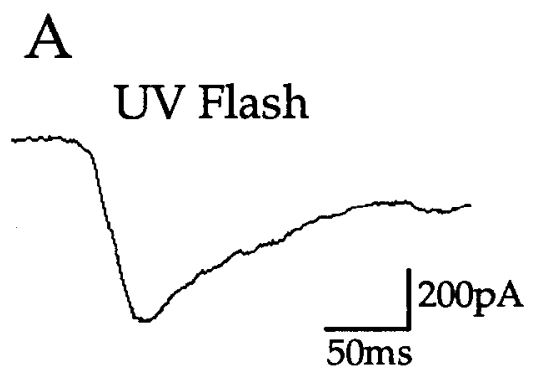

B
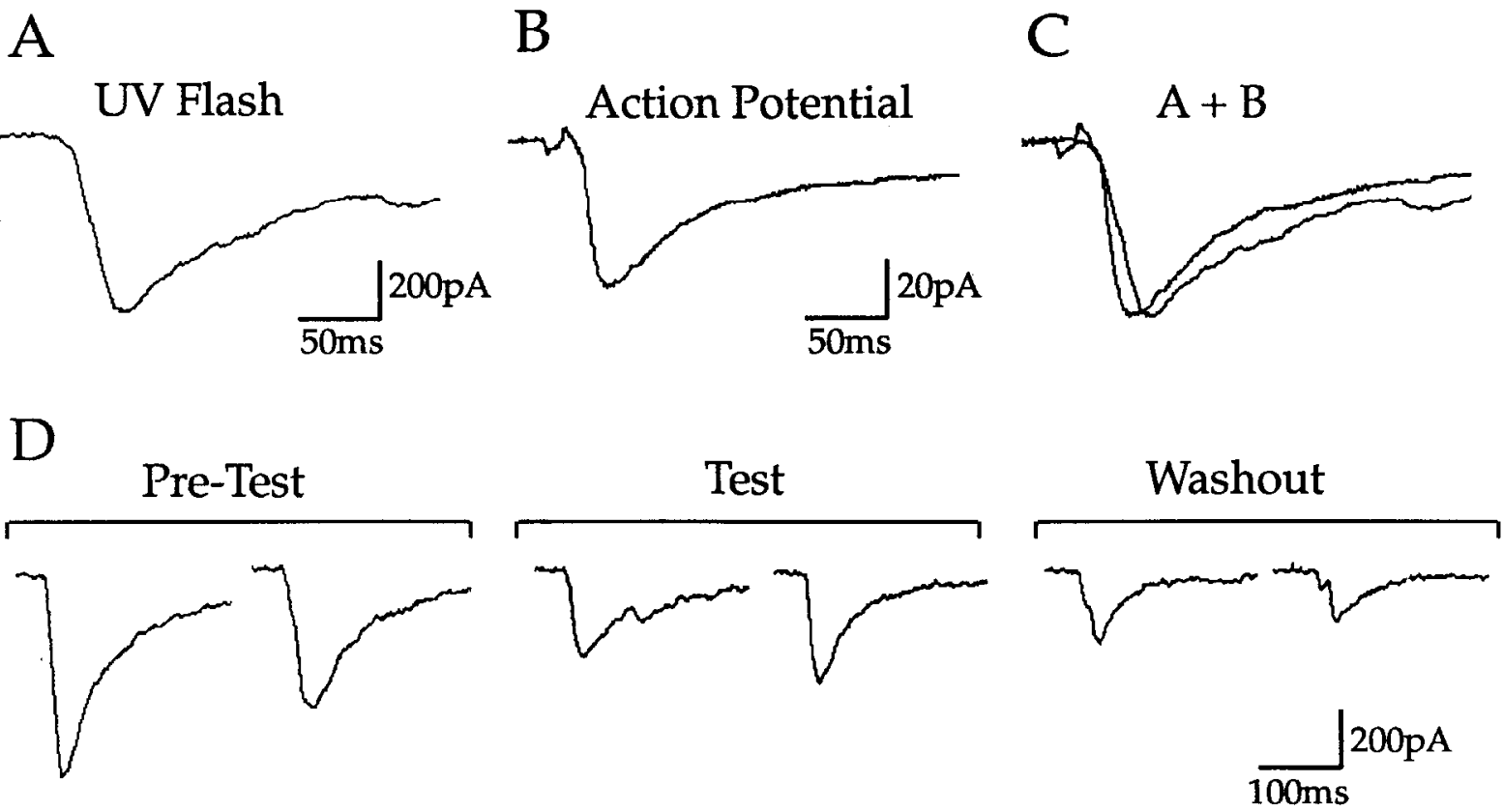

Figure 1. UV photolysis of DM-nitrophen promotes the synchronized release of neurotransmitter. Presynaptic somata were injected with calciumloaded DM-nitrophen and fluo-3 and postsynaptic currents in voltage-clamped (holding potential, $-80 \mathrm{mV}$ ) postsynaptic somata were recorded. $A$, Photolysis $(15 \mathrm{msec})$ caused a large transient IPSC. $B$, An action potential in the presynaptic cell of the same synapse promoted a similar IPSC, although the action potential-evoked IPSC was characteristically smaller than photolysis-evoked IPSCs (note that the gain in $A$ is 0.1 of that in $B$ ). The artifact preceding the IPSC in $B$ is due to the stimulus pulse applied to the presynaptic cell. In $C$, flash-and action potential-evoked IPSCs seen in $A$ and $B$ are normalized and superimposed. The time course of the flash-evoked IPSC is similar to the action potential-evoked IPSC. $D$, Flash photolysis repeatedly promotes transmitter release, although the amplitudes of successive IPSCs become smaller. Postsynaptic responses to six $15 \mathrm{msec}$ UV flashes are shown. Flashes were provided in the paradigm used to test the effects of FMRFamide on synchronized, calcium-clamped synaptic transmission. Pairs of UV flashes ( 2 min interflash interval) were provided in three groups: pretest, test, and washout. A 5 min rest period was provided between each group of recordings. The small increase in IPSC amplitude following the fourth flash is within the normal range of variability during rundown of flash-evoked synaptic transmission.

examples of IPSCs obtained from control (Fig. $2 A$ ) and experimental (Fig. $2 B$ ) preparations. The average of two IPSCs during the pretest (1) and the average of two IPSCs during test (2) periods are superimposed. In the control preparation (Fig. $2 A$ ), the characteristic rundown of flash-evoked release can be seen. Comparison to Figure $2 B$ shows that the amplitude of the IPSCs in the experimental preparation in the presence of FMRFamide (Fig. 2B, trace 2) is smaller than the amplitude of IPSCs in the test period of the control preparation (Fig. $2 A$, trace 2). In $10^{-6}$ M FMRFamide, IPSCs had a normalized value of $0.28 \pm 0.07$ $(n=7)$ compared to $0.69 \pm 0.19(n=6)$ in parallel control preparations $(p<0.05$, one-tailed $t$ test). Figure $2 C$ presents these data as a ratio of the values of the experimental to control preparations within each period. FMR Famide $\left(10^{-6} \mathrm{M}\right)$ reduced the ratio of IPSC amplitude from a value of 1.0 in the pretest period to $0.40 \pm 0.11$ in the test period. Following washout of FMRFamide, there is little recovery in the IPSC amplitude, the ratio increasing to only $0.48 \pm 0.17$. Since FMRFamide does not affect postsynaptic sensitivity to released neurotransmitter (Man-Son-Hing et al., 1989; Haydon, unpublished observations), these data demonstrate that the pool of neurotransmitter released under conditions of a rapid elevation of calcium is modulated by the peptide FMRFamide.

\section{Quantal release of neurotransmitter}

For studies of secretory machinery, it is preferable to use a stable index of synaptic function in which rundown is not present. One such index is provided by monitoring the spontaneous release of neurotransmitter. To determine whether action potential- evoked IPSC comprises the same event as spontaneously occurring MIPSCs, we compared the amplitudes and kinetic properties of these two types of neurotransmitter release.

The amplitudes of spontaneous MIPSCs and spike-evoked IPSCs from four preparations were measured under conditions of elevated extracellular $\mathrm{Mg}^{2+}$, which reduces the quantal content of synaptic transmission. Extracellular $\mathbf{M g}^{2+}$ was elevated so that the magnitude of evoked IPSCs was reduced and preparations exhibited failures in synaptic transmission. Figure $3 A$ shows the amplitude distribution for spontaneously occurring MIPSCs in one preparation. The quantal size of MIPSCs was $23.5 \pm 8.1 \mathrm{pA}$. A Gaussian distribution is superimposed on the raw data in Figure $3 A$. Action potentials were evoked presynaptically, and the amplitudes of IPSCs were measured; 200 action potentials evoked 113 IPSCs with 87 failures. Knowing the proportion of failures, we calculated the quantal content of synaptic transmission to be 0.8 . Division of the mean amplitude of the evoked IPSC (16.8 pA) by the quantal size, $q(23.5 \mathrm{pA})$, estimates the quantal content, $m$, to be 0.72 . Knowing $m, q$, and the SD of $q$, we used Poisson statistics to estimate the frequency of failures, and incidence of one, two, and three quanta released by presynaptic action potentials. The sum of three Gaussian curves showing such predicted data is superimposed on the raw frequency distribution histogram of evoked IPSC amplitudes in Figure $3 B$. The predicted and observed distributions were not significantly different $\left(\chi^{2}, p>0.1\right)$. The insets to Figure 3, $A$ and $B$, show representative examples of MIPSCs and cvoked IPSCs. These traces clearly have the same kinetic features. Similar data were obtained in each of the four prep- 


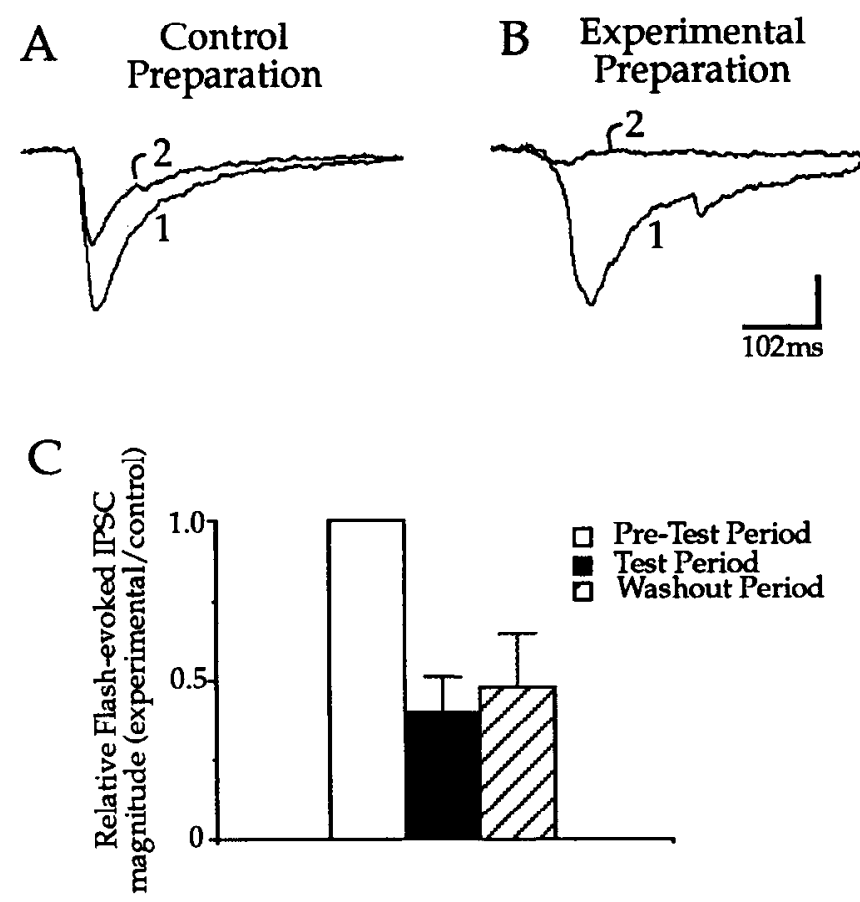

Figure 2. FMRFamide reduces the magnitude of calcium-clamped synchronized synaptic transmission. Six UV flashes were provided to DM-nitrophen-loaded synapses, and the average of two flash-evoked IPSCs during the pretest period (trace 1 ) and test period (trace 2) is shown in $A$ and $B$. $A$, Flash-evoked IPSCs in a control preparation. The reduction in average IPSC amplitude between the control and test periods represents the normal intertrial rundown of synaptic transmission seen in these calcium-clamp experiments. $B$, Flash-evoked IPSCs in an experimental preparation that was exposed to $10^{-6} \mathrm{M}$ FMRFamide during the test period (trace 2). The amplitude of the average IPSC in the presence of FMRFamide (trace 2 in $B$ ) is smaller than in control preparations (trace 2 in $A$ ). Traces are normalized for IPSC magnitude during the pretest period for comparison between preparations. $C$, Histograms showing the relative flash-evoked IPSC size as a ratio of experimental to control preparations. Addition of FMRFamide $\left(10^{-6} \mathrm{M}\right)$ reduces the synchronized synaptic current to $0.4(n=7)$ of the current magnitudc in control preparations $(n=7)$. Calibration: $A, 90 \mathrm{pA} ; B, 100 \mathrm{pA}$.

arations studied. The mean unitary MIPSC size was $12.5 \pm 3.97$ $\mathrm{pA}(n=4$; range, $5-24 \mathrm{pA})$. Taken together, these data indicate that action potentials cause the quantal release of neurotransmitter.

\section{FMRFamide reduces the frequency of MIPSCS}

Dalc and Kandel (1990) have shown that a change in the frequency of spontaneous EPSPs at cell-cultured Aplysia sensorymotor synapses is correlated with the modulation of secretory machinery. To monitor presynaptic secretory machinery, we recorded the frequency of spontaneous MIPSCs. Since there was considerable intersynaptic variability in the frequency of spontaneous MIPSCs, we have expressed MIPSC frequency as values normalized to the average frequency obtained during the initial $5 \mathrm{~min}$ pretest recording period from the same synapse.

Bath application of FMRFamide $\left(10^{-6} \mathrm{M}\right)$ reliably reduced the frequency of MIPSCs $(n=7)$. FMRFamide reduced the MIPSC frequency from a normalized pretest value of 1.0 to 0.71 \pm 0.12 , a $29 \%$ reduction in MIPSC frequency (Fig. 4). Five minutes after FMRFamide washout, the frequency of MIPSCs returned to a value of $1.10 \pm 0.13$. The MIPSC frequency ranged from 4 and 49 MIPSCs/min in these preparations. No corre-

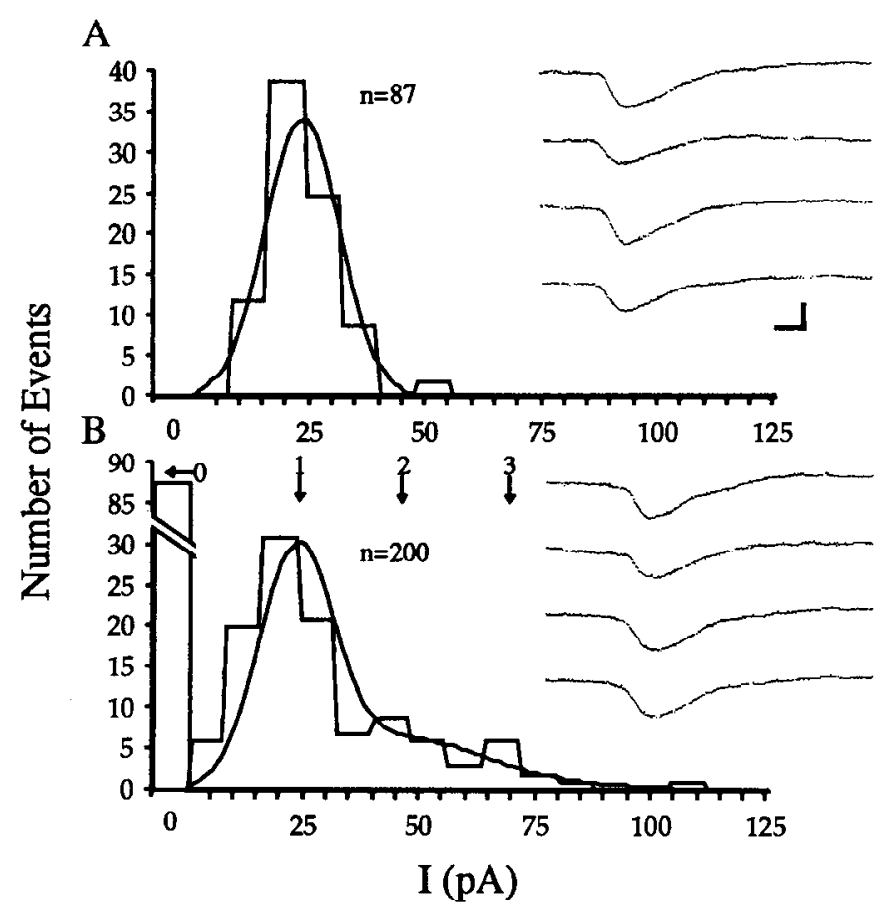

Figure 3. Spontaneous MIPSCs are the quantal event underlying action potential-evoked synaptic transmission. $A$, An amplitude distribution histogram of spontaneous MIPSCs from a single preparation that have a mean amplitude of $23.5 \pm 8.1 \mathrm{pA}$ (mean $\pm \mathrm{SD} ; n=87$ ). A single Gaussian curve is superimposed on the histogram. $B$, An amplitude distribution histogram of the action potential-evoked IPSCs $(n=$ $200 ; 113$ IPSCs, 87 failures) in the same preparation as $A$. The sum of three Gaussian curves is fit to the data using the mean and SD obtained from the spontaneous MIPSCs in $A$. Arrows indicate the predicted number of failures of synaptic transmission, and the magnitude of 1,2 , and 3 quanta, if the evoked IPSC is due to a quantal event represented by the MIPSC. Insets in $A$ and $B$ show raw current traces of spontaneous MIPSCs and evoked IPSCs, respectively. The evoked IPSC has the same kinetic features as the MIPSC. Calibration: $20 \mathrm{pA}, 20 \mathrm{msec}$.

lation was found between initial MIPSC frequency and the extent of FMRFamide's modulation of MIPSC frequency. The inhibitory action of FMRFamide on MIPSC frequency was surprisingly slow. In a previous report (Man-Son-Hing et al., 1989) where nitr-5 was used to control internal calcium, we showed that FMRFamide acts on secretory machinery within seconds of application (see Fig. $2 c$ of Man-Son-Hing et al., 1989). In the present experiments, however, where resting calcium levels and MIPSC frequency were both relatively low, FMRFamide was present for minutes before an action on MIPSC frequency was reliably revealed (Fig. 4A).

Previous calcium-clamp experiments (Man-Son-Hing et al., 1989; also Fig. 2 above) demonstrated that FMRFamide's inhibitory effect on MIPSC frequency is due to a direct effect on secretory apparatus, rather than on internal calcium levels. Using fura-2 to detect internal free $\mathrm{Ca}^{2+}$, we detected no change in internal free $\mathrm{Ca}^{2+}$ during FMRFamide application in the present experiments. The addition of FMRFamide for $5 \mathrm{~min}$ periods in concentrations ranging from $10^{-6}$ to $10^{-4} \mathrm{M}$ did not change the resting free calcium level in the presynaptic soma. The lack of effect of FMRFamide on resting calcium levels at these concentrations, which are up to 5 orders of magnitude greater than the concentration required for modulating MIPSC frequency (see below), supports our previous observation that 

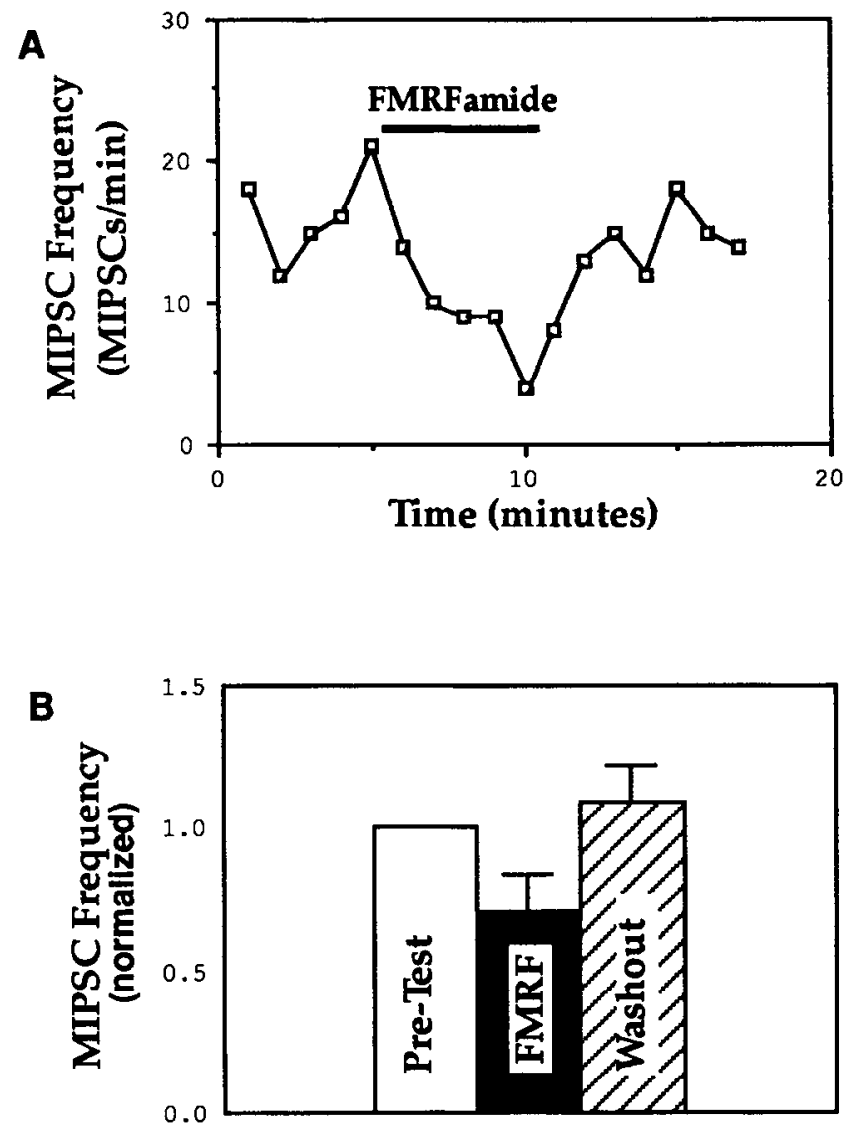

Figure 4. FMRFamide reduces the frequency of MIPSCs. $A$, MIPSC frequency in a representative preparation. Addition of $10^{-6} \mathrm{M}$ FMRFamide reversibly reduced the frequency of MIPSCs. $B$, Cumulative data from seven preparations.

FMRFamide can regulate the secretory response to a constant level of internal calcium (Fig. 2; Man-Son-Hing et al., 1989; see Discussion).

\section{Injection of guanine nucleotides}

To begin to determine whether FMRFamide acts through a G-protein-mediated signal transduction pathway, a nonhydrolyzable analog of GTP, GTP $\gamma$ S, was injected into the presynaptic soma while recording the frequency of MIPSCs. GTP $\gamma \mathrm{S}$ injection $(n=4)$ reduced the frequency of MIPSCs over a period of 5 min following microinjection (Fig. 5A). The actions of GTP and GTP $\gamma$ S injection were quantified by calculating the mean MIPSC frequency during the fourth and fifth minutes following microinjection. GTP $\gamma \mathrm{S}$ injection $(n=4)$ reduced the frequency of MIPSCs to a value $0.26 \pm 0.03$ of the preinjection value, while GTP injection $(n=3)$ only reduced the rate to $0.64 \pm$ $0.12(p<0.002$, two-tailed $t$ test). This action of GTP $\gamma \mathrm{S}$ is consistent with a G-protein-activated pathway exerting an inhibitory effect on MIPSC frequency.

\section{PTX prevents FMRFamide's inhibitory effect on secretory machinery}

To test more critically for a G-protein requirement for FMRFamide to act on secretory machinery, and to begin to identify the class of G-protein mediating this inhibitory effect, we injected the A-protomer of PTX into the presynaptic soma. Fifteen minutes after injection, the baseline frequency of MIPSCs
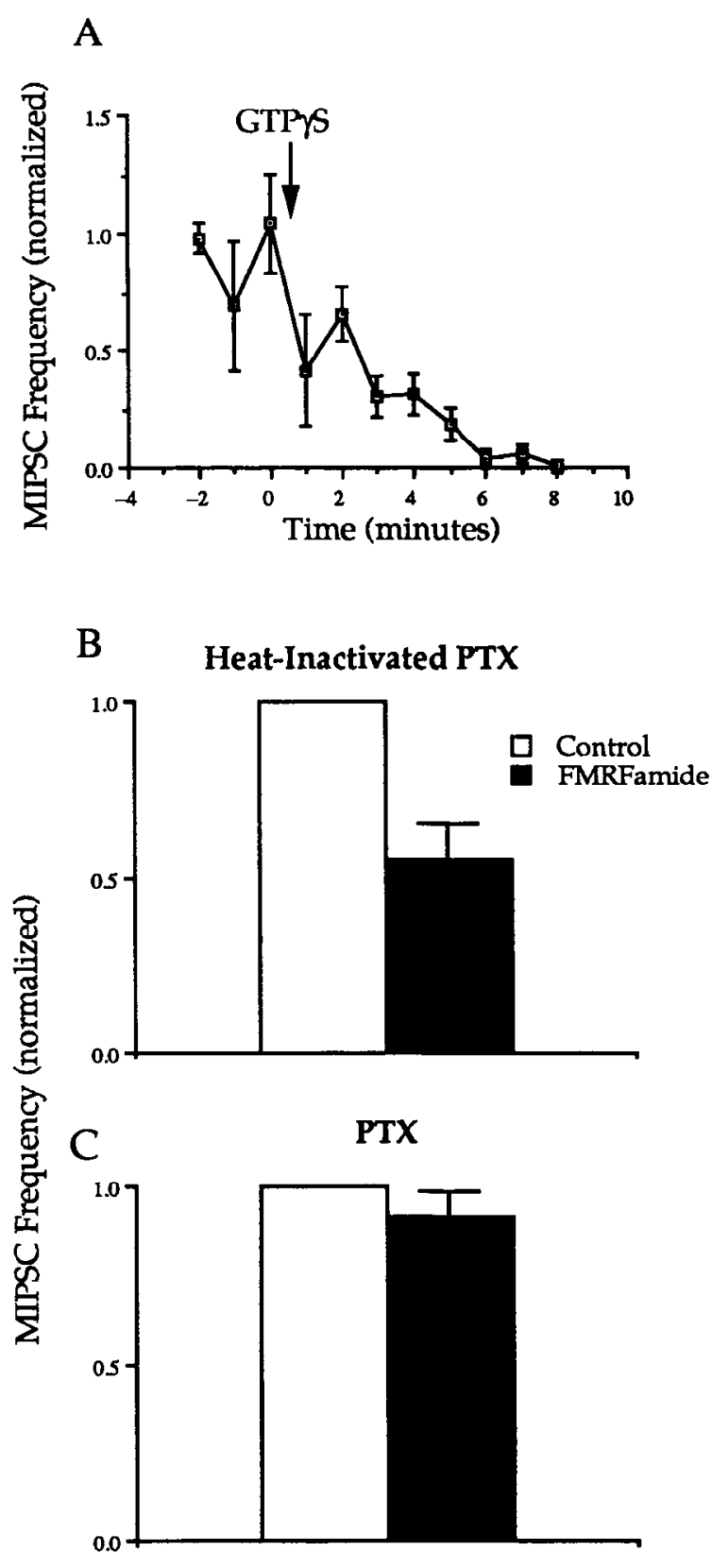

Figure 5. A PTX-sensitive G-protein mediates the action of FMRFamide on secretory apparatus. $A$, The average MIPSC frequency $(n=4)$ before and after injection of $\mathrm{GTP} \gamma \mathrm{S}$ into the presynaptic cytoplasm. GTP $\gamma$ S injection caused a sustained, time-dependent reduction in MIPSC frequency. Presynaptic somata were injected either with heatinactivated PTX $(n=5 ; B)$ or with the A-protomer of PTX $(n=4 ; C)$ $20 \mathrm{~min}$ prior to FMRFamide $\left(10^{-6} \mathrm{M}\right)$ addition. PTX injection attenuates the action of the peptide on MIPSC frequency. Histograms show the normalized MIPSC frequency during the control period and in the presence of FMRFamide $\left(10^{-6} \mathrm{M}\right)$.

was measured for a control $5 \mathrm{~min}$ pcriod. The frequency of MIPSCs was not significantly different between PTX-injected $(12.8 \pm 3.9 \mathrm{pA}$, mean $\pm \mathrm{SD})$ and heat-inactivated PTX-injected cells $(18.3 \pm 13.5 \mathrm{pA}$, mean $\pm \mathrm{SD})$. Twenty minutes after injection, the effect of FMRFamide was determined. Following PTX injection, FMRFamide had a significantly attenuated inhibitory action on secretory machinery (Fig. 5C). In PTX injected cells, FMRFamide $\left(10^{-6} \mathbf{M}\right)$ reduced the frequency of MIPSCs from a control value of 1.0 to $0.92 \pm 0.07(n=4)$ as 
$\mathbf{A}$

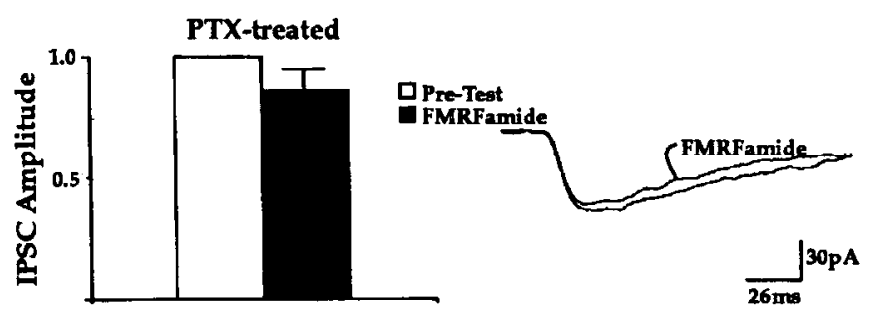

B
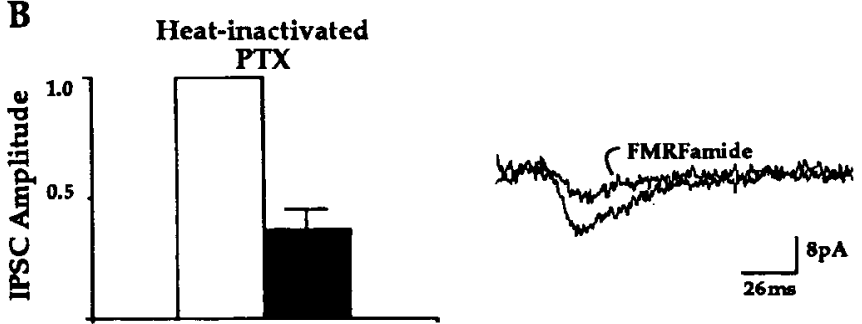

Figure 6. PTX injection prevents FMRFamide from reducing the amplitude of action potential-evoked IPSCs. The A-protomer of PTX ( $A$ $n=5)$ or heat-inactivated PTX $(B ; n=5)$ was microinjected into presynaptic soma. Subsequently, the amplitudes of spike-evoked IPSCs were determined in a pretest period and after addition of $10^{-6} \mathrm{M}$ FMRFamide. $A$, PTX prevents the inhibitory action of FMRFamide on action potential-evoked synaptic transmission. $B$, Injection of heatinactivated PTX does not prevent FMRFamide from reducing synaptic transmission. Raw traces in $A$ and $B$ show action potential-evoked IPSCs in the pretest period and in the presence of $10^{-6} \mathrm{M}$ FMRFamide.

compared to $0.55 \pm 0.01(n=5)$ in control preparations injected with the PTX carrier or with heat-inactivated PTX (Fig. $5 B ; p$ $<0.02$, Student's one-tailed $t$ test). Thus, FMRFamide acts through a PTX-sensitive G-protein to reduce the frequency of MIPSCs.

\section{A PTX-sensitive G-protein mediates FMRFamide's modulatory actions on synaptic transmission}

Since we have demonstrated that a PTX-sensitive G-protein is involved in mediating FMRFamide's actions on secretory machinery (Fig. 5) as well as on ion channels (Man-Son-Hing et al., 1991), we determined whether a similar class of G-protein mediates FMRFamide's actions on the modulation of action potential-evoked synaptic transmission. Presynaptic somata were preinjected with the A-protomer of PTX up to $4 \mathrm{hr}$ prior to recording. Following PTX injection, FMRFamide $\left(10^{-6} \mathbf{M}\right)$ had little modulatory effect on action potential-evoked synaptic transmission. FMRFamide reduced the evoked IPSC from a pretest value of 1.0 to $0.86 \pm 0.09(n=5$; Fig. $6 A)$, while in control preparations injected with heat-inactivated PTX, FMRFamide $\left(10^{-6} \mathrm{M}\right)$ reduced synaptic transmission from 1.0 to $0.35 \pm 0.09(n=5 ; p<0.002$, two-tailed $t$ test; Fig. $6 B)$. Thus, PTX-sensitive G-proteins are involved in mediating actions of FMRFamide on the presynaptic calcium current (ManSon-Hing et al., 1991), on secretory machinery (Fig. 5), and on action potential-evoked synaptic transmission (Fig. 6).

\section{Dose-response curves for the actions of FMRFamide}

To begin to quantify the contribution of the modulation of secretory machinery and calcium channels to the modulation of action potential-evoked release of neurotransmitter, we constructed dose-response curves for each component. Somata of
A

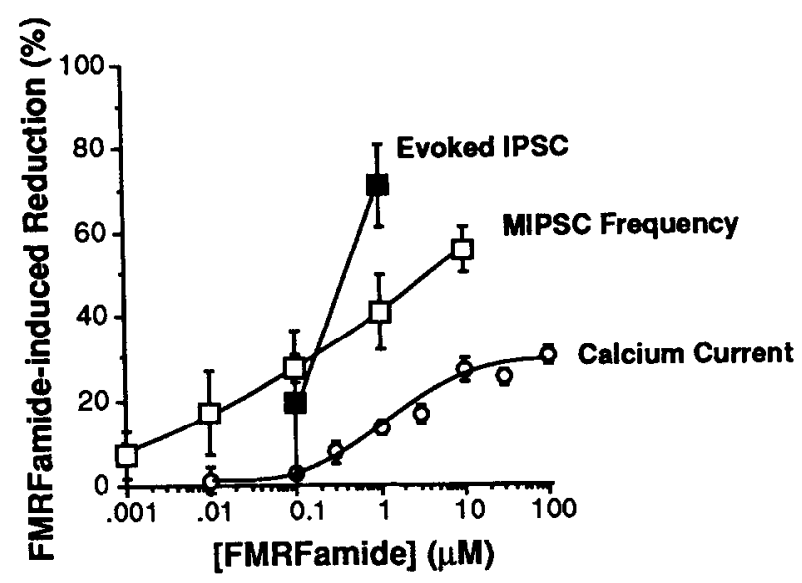

B

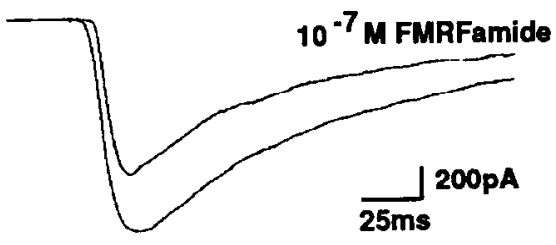

Figure 7. Dose-response curves for the modulatory effects of FMRFamide on secretory machinery and calcium current. $A, 10^{-9} \mathrm{M}$ FMRFamide can reduce the frequency of MIPSCs (open squares), while $3 \times 10^{-7}$ M FMRFamide is required for significant modulatory action on the calcium current (open circles). The modulation of evoked IPSCs (solid squares) at $10^{-7} \mathrm{M}$ FMRFamide can be accounted for by the regulation of secretory machinery. At $10^{-6} \mathrm{M}$ FMRFamide, the modulation of the evoked IPSC is greater than the modulation of secretory machinery alone and is likely to be due to combinatorial effects of FMRFamide modulating calcium influx and secretory machinery. Data are shown as means \pm SEM. $B$, Superimposed evoked IPSCs. Addition of FMRFamide $\left(10^{-1} \mathrm{M}\right)$ reduces evoked synaptic transmission.

neuron B5 were voltage clamped in the whole-cell configuration and depolarized from a holding potential of $-60 \mathrm{mV}$ to a command potential $(0-20 \mathrm{mV})$ to evoke the maximum magnitude of HVA calcium current in the cell (Haydon and Man-Son-Hing, 1988). Addition of FMRFamide at concentrations of $3 \times 10^{-7}$ $M$, or greater, reversibly reduced the calcium current magnitude (Fig. 7). This action is judged to be a reduction in a calcium current rather than an increase in potassium current, since (1) addition of $\mathrm{Cd}^{2+}$ reduces both the calcium current magnitude and the extent of FMRFamide's modulation of the calcium current, (2) FMRFamide does not change the positive reversal potential of the calcium current, and (3) FMRFamide causes the same relative reduction in calcium current magnitude at all command potentials (Man-Son-Hing et al., 1989).

To determine quantitatively the action of FMRFamide on secretory machinery, MIPSC frequency was measured. FMRFamide reduced the frequency of MIPSCs at concentrations as low as $10^{-9} \mathrm{M}$ (Fig. 7). Thus, FMRFamide can act on secretory machinery at a concentration 2 orders of magnitude lower than on the HVA calcium current.

\section{Reduction in action potential-evoked IPSC magnitude}

We determined whether low doses of FMRFamide, which modulate MIPSC frequency but have no significant effect on calcium 
current magnitude, will modulate action potential-evoked synaptic transmission. Single action potentials were evoked in the presynaptic cell at $1-5$ min intervals while recording the magnitude of the evoked IPSC. The IPSC magnitude is variable between preparations and may range from about 20 to 1000 pA. However, the extent of FMRFamide's modulation is consistent irrespective of IPSC size. Action potential-evoked IPSCs were reduced in amplitude by $19 \pm 17 \%$ by addition of $10^{-3} \mathrm{M}$ FMRFamide ( $n=7$ in three preparations; Fig. 7). This modulation of spike-evoked release can be accounted for by the selective modulation of secretory machinery since $10^{-7} \mathrm{M}$ FMRFamide reduced MIPSC frequency by $27 \pm 3 \%$. FMRFamide at $10^{-6} \mathrm{M}$ reduced the action potential-evoked IPSC by 71 $\pm 10 \%(n=5)$. This reduction in evoked IPSC amplitude is likely a result of the combined modulation of secretory machinery and the calcium current since $10^{-6} \mathrm{M}$ FMRFamide reduced MIPSC frequency by $41 \pm 9 \%$ and reduced the calcium current by $13 \pm 2 \%$ of control values (Fig. 7).

\section{Discussion}

The neuropeptide FMRFamide, which is endogenous to the nervous system of Helisoma (Murphy et al., 1985; Bulloch et al., 1988; Richmond et al., 1991), causes a presynaptic inhibition of ACh release from neuron B5 (Man-Son-Hing et al., 1989). In addition to affecting action potential-evoked synaptic transmission and the magnitude of a voltage-sensitive calcium current, FMRFamide also reduces MIPSC frequency. This reduction in MIPSC frequency is judged to be due to an action on secretory machinery since the calcium-sensitive fluorophore fura-2 did not detect a FMRFamide-induced change in free calcium even at a peptide concentration 5 orders of magnitude greater than the threshold concentration for affecting MIPSC frequency. While it is possible that a subplasma-membrane change in calcium concentration could go undetected in such experiments, additional evidence supports the modulation of secretory machinery per se. For example, FMRFamide reduces MIPSC frequency when the presynaptic soma is filled with an experimentally injected calcium chelator that becomes the dominant calcium buffer (Man-Son-Hing et al., 1989). FMRFamide modulates MIPSC frequency at concentrations that do not affect calcium influx (Fig. 7), and FMRFamide reduces the synchronized IPSC amplitude evoked by flash photolysis of DM-nitrophen (Fig. 2). Taken together, this evidence demonstrates that FMRFamide modulates secretory machinery by reducing its responsiveness to internal $\mathrm{Ca}^{2+}$.

\section{$G$-protein requirement for secretory machinery modulation}

The injection of the nonhydrolyzable analog of GTP, GTP $\gamma$ S, significantly depressed the frequency of MIPSCs. Further, PTX attenuated the inhibitory action of $10^{-6} \mathrm{M}$ FMRFamide on MIPSC frequency. Taken together, these data demonstrate the involvement of a PTX-sensitive G-protein in mediating FMRFamide's action on secretory machinery. Similarly, ManSon-Hing and Haydon (1990) demonstrated that a PTX-sensitive G-protein mediates the action of FMRFamide on the presynaptic calcium current of this same neuron. Whether the same or different G-proteins mediate these two actions of FMRFamide on calcium current and secretory machinery is unknown.

G-protein-dependent modulation of secretory machinery has been demonstrated in insulin-secreting cells. Addition of noradrenaline to isolated islets of Langerhans inhibits glucose-in- duced insulin secretion (Jones et al., 1987). Using permeabilized islets in the presence of $\mathrm{Ca}^{2+} /$ EGTA, Jones et al. (1987) also showed that $\mathrm{Ca}^{2+}$-stimulated secretion is reduced by noradrenaline. Using isolated, single insulin-secreting RINm 5 F cells, Ullrich and Wollheim (1988) demonstrated that this inhibitory step is blocked by preincubation with PTX, indicating a G-protein regulation of secretory machinery.

Studies in non-heural cells indicate that $G$-proteins may be involved in a late step controlling exocytosis (Gomperts, 1990). The introduction of nonhydrolyzable analogs of GTP into a variety of cells can stimulate $\mathrm{Ca}^{2+}$-independent secretion. Guanine nucleotide-dependent secretion can be triggered in adrenal medullary cells (Knight and Baker, 1985), adrenal chromaffin cells (Bittner et al., 1986), neutrophils (Barrowman et al., 1986), parathyroid cells (Oetting et al., 1986), and mast cells (Fernandez et al., 1984). There is some crossover between guanine nucleotide-stimulated secretion and $\mathrm{Ca}^{2+}$-dependent secretion since GDP $\beta$ S inhibits guanosine $5^{\prime}-(\beta \gamma$-imido triphosphate (GMP-PNP)-dependent secretion and partially inhibits $\mathrm{Ca}^{2+}$. dependent secretion in chromaffin cells (Bittner et al., 1986). The stimulatory effects of GTP $\gamma \mathrm{S}$ and GMP-PNP have led to the suggestion that there is an as of yet unidentified $G$-protein, $\mathrm{G}_{\mathrm{E}}$, which is involved in one of the later steps controlling exocytosis. There is no cvidence to support the presence of $G_{E}$ in neural tissue. $\mathrm{Ca}^{2+}$-dependent secretion from permeabilized nerve endings isolated from rat neurohypophysis does not require the presence of GTP (Cazalis et al., 1987), although GTP addition can enhance $\mathrm{Ca}^{2+}$-dependent secretion. GTP $\gamma \mathrm{S}$ injection into squid giant presynaptic terminal reduces synaptic transmission (Hess and Augustine, 1990). This action is mediated at least in part through effects on presynaptic ion channels, and the G-protein modulation of secretory machinery is currently undefined (Hess and Augustine, 1990). Injection of GTP $\gamma$ S into the secretory soma of neuron B5 caused a reduction in MIPSC frequency. An elevation of MIPSC frequency was not detected. Thus, in this nerve terminal we have no evidence to support the existence of a $\mathrm{G}_{\mathrm{E}}$-like $\mathrm{G}$-protein. We cannot discount the possibility that the inhibitory action of the PTXsensitive $\mathrm{G}$-protein is overriding a stimulatory effect of a $G_{E}$ following GTP $\gamma \mathrm{S}$ injection.

\section{Vesicle mobilization}

There are multiple mechanisms that may mediate the action of FMRFamide on secretory machinery. For example, FMRFamide might reduce the transmitter pool available for exocytosis. By injecting purified synapsin I, a vesicle-associated protein, and $\mathrm{Ca}^{7+} /$ calmodulin-dependent protein kinase II into the squid giant synapse, Llinas et al. (1985) demonstrated that the state of phosphorylation of synapsin I can modulate the release of transmitter in response to a constant calcium influx. Injection of dephospho-synapsin I reduced transmitter release. Injection of $\mathrm{Ca}^{2+} /$ calmodulin-dependent protein kinase II, which phosphorylates synapsin I, enhanced transmitter release. Using video-enhanced microscopy, McGuiness et al. (1989) demonstrated that dephospho-synapsin I inhibits organelle movement along extruded microtubules, while phosphorylation of synapsin I removed such inhibitory effects. Assuming that similar immobilizing actions could be exerted by actin, a synapsin-binding protein of nerve terminals, such results suggest that dephosphosynapsin I regulates the amount of transmitter released by crosslinking synaptic vesicles with cytoskeleton, reducing vesicle mobilization and the available pool of transmitter for release. It is 
unknown whether FMRFamide is acting through such a mechanism.

In Aplysia, FMRFamide's effects on " $S$ " type K channels have been shown to act through a phospholipase and promote the release of arachidonic acid metabolites (Piomelli et al., 1987). Piomelli et al. (1989) recently demonstrated that arachidonic acid and lipoxygenase-derived eicosanoids selectively inhibit $\mathrm{Ca}^{2+/}$ calmodulin-dependent protein kinase II activity. Thus, the arachidonic acid-derived metabolites are good candidates for mediating the actions of FMRFamide on secretory machinery through the inhibition of $\mathrm{Ca}^{2+}$-calmodulin-dependent protein kinase II (Piomelli and Greengard, 1990). Alternatively, FMRFamide may have similar effects through the activation of protein phosphatases (Ichinose et al., 1990).

In the experiments described herein, MIPSC frequency was not reduced until minutes had elapsed following addition of FMRFamide. This is in contrast to a previous report (Man-SonHing et al., 1989) where we demonstrated that MIPSC frequency is reduced within seconds of FMRFamide application. In those previous experiments, internal calcium was experimentally elevated using the photolabile calcium cage nitr-5, which promoted an accelerated frequency of MIPSCs. The kinetic distinction between FMRFamide's rate of action in these two sets of experiments could be related either to the different calcium levels or to different MIPSC frequencies. Perhaps there is a calcium-sensitive component to the signal transduction pathway, such as phospholipase $A_{2}$, for the actions of FMRFamide. Alternatively, the cycling rate of synaptic vesicles may affect the kinetics of FMRFamide action. Based on the observations of Llinas et al. (1985) and McGuiness et al. (1989) in squid, FMRFamide may affect the ability of synaptic vesicles to be mobilized from a nonreleasable pool to the pool of vesicles docked at the plasma membrane that are available for release. If FMRFamide affects such a mobilization process, the kinetics of peptide action would be related to the frequency of exocytosis, since at higher MIPSC frequencies, vesicle depletion and mobilization would come into play more rapidly.

Ultrastructural evidence indicates that the transmitter pool immediately available for release is dynamic. In Aplysia, Bailey and Chen (1988) have investigated the ultrastructural modifications of sensory neuron terminals following periods of behavioral training that promote synaptic plasticity. Under training conditions that lead to short-term homosynaptic depression, the number of vesicles available for release (vesicles within 30 $\mathrm{nm}$ of the active zone) is markedly reduced while the total number of vesicles is unaffected. Thus, experimental evidence demonstrates that short-term perturbations can lead to alterations in the transmitter pool available for release, and leaves open the possibility that FMRFamide acts in such a manner.

The plasticity of synaptic transmission at sensory-motor synapses in Aplysia is regulated by changes in calcium influx (Blumenfeld et al., 1990) and by effects on secretory machinery (Dale and Kandel, 1990). The neuromodulatory transmitter 5-HT facilitates synaptic transmission. Hochner et al. (1986) demonstrated that under conditions of homosynaptic depression, 5-HT has a facilitatory action on synaptic transmission through a process other than spike broadening and channel modulation and suggest that this may be due to a mobilization of vesicles from a storage pool to the available transmitter pool. Modeling studies of Gingrich and Byrne (1985) show that the mobilization of vesicles to the available transmitter pool can account for this result. FMRFamide reduces synaptic transmission at sensory- motor synapses (Piomelli et al., 1987). In addition to the modulation of ion channels (Belardetti et al., 1987), FMRFamide prevents the 5-HT-induced activation of the second process of facilitation (Pierioni and Byrne, 1990), which involves the modulation of secretory machinery.

In IIelisoma, secretory machinery is affected by FMRFamide at concentrations lower than those required for actions on the calcium current. FMRFamide at $10^{-7} \mathbf{M}$, which has insignificant effects on the voltage-sensitive calcium current, does affect secretory machinery and causes a small reduction in synaptic transmission. Since there is a nonlinear relation between calcium current and neurotransmitter release (Augustine et al., 1985), we cannot discount the possibility that a small reduction in calcium current magnitude is contributing to the modulation of transmitter release. However, the reduction of transmitter release can be accounted for solely by the modulation of secretory machinery at $10^{-7} \mathrm{M}$ FMRFamide (Fig. $7 A$ ). By contrast, at $10^{-6} \mathrm{M}$ FMRFamide, both the modulation of calcium current and secretory machinery are required to account for the reduction of IPSC amplitude (Fig. $7 A$ ). Our data at $10^{-7}$ M FMRFamide are in support of a previous observation that demonstrated that synaptic modulation can arise due to the regulation of secretory machinery alone (Llinas et al., 1985). This selective modulation of secretory machinery permits the regulation of synaptic output without affecting the presynaptic ion conductances and integrative properties of this neuron.

Modulators of synaptic transmission might act at the level of secretory apparatus in a variety of synapses. Dephospho-synapsin I injection decreases transmitter release in the squid giant synapse (Llinas et al., 1985) and reduces the quantal content $(m)$ of synaptic transmission at goldfish Mauthner synapses (Hackett et al., 1990). Phorbol esters (Malenka et al., 1987) and neurotransmitters (Dale and Kandel, 1990) that promote synaptic plasticity can concomitantly change the frequency of spontaneous miniature potentials. Adenosine and its analogs modulate miniature end plate potential frequency coincidently with evoked transmission at the neuromuscular junction (Silinsky, 1984; Singh et al., 1986). Thus, the modulation of secretory machinery might be an important site that underlies synaptic plasticity in many synapses.

\section{References}

Augustine GJ, Charlton MP, Smith SJ (1985) Calcium entry and transmitter release at voltage-clamped nerve terminals of squid. J Physiol (Lond) 369:163-181.

Bailey CH, Chen M (1988) Morphological basis of short-term habituation in Aplysia. J Neurosci 8:2452-2459.

Barrowman MM, Cockfort S, Gomperts BD (1986) Two roles for guanine nucleotides in the stimulus-secretion sequence in neutrophils. Nature 319:504-507.

Belardetti F, Kandel ER, Siegelbaum SA (1987) Neuronal inhibition by the peptide FMRFamide involves opening of $\mathrm{S} \mathrm{K}^{+}$channels. $\mathrm{Na}-$ ture 325:153-156.

Bittner MA, Holz RW, Neubig RR (1986) Guanine nucleotide effects on catecholamine secretion from digitonin-permeabilized adrenal chromaffin cells. J Biol Chem 261:10182-10188.

Blumenfeld H, Spira ME, Kandel ER, Siegelbaum SA (1990) Facilitatory and inhibitory transmitters modulate calcium influx during action potentials in Aplysia sensory neurons. Neuron 5:487-499.

Brezina V (1988) Guanosine 5'-triphosphate analogue activates potassium current modulated by neurotransmitters in Aplysia neurones. J Physiol (Lond) 407:15-40.

Brezina V, Eckert R, Erxleben C (1987) Suppression of calcium current by an endogenous neuropeptide in neurones of Aplysia californica. J Physiol (Lond) 388:565-595.

Bulloch AGM, Price DA, Murphy AD, Lee TD, Bowes HN (1988) 
FMRFamide peptides in Helisoma: identification and physiological actions at a peripheral synapse. J Neurosci 8:3459-3469.

Castellucci VF, Pinsker H, Kupfermann I, Kandel ER (1970) Neuronal mechanisms of habituation and dishabituation of the gill-withdrawal reflex in Aplysia. Science 194:1176-1178.

Cazalis M, Dayanithi G, Nordmann JJ (1987) Requirements for hormone release from permeabilized nerve endings isolated from the rat neurohypophysis. J Physiol (Lond) 390:71-91.

Cohan CS, Connor JA, Kater SB (1987) Electrically and chemically mediated increases in intracellular calcium in neuronal growth cones. J Neurosci 7:3588-3599.

Dale N, Kandel ER (1990) Facilitatory and inhibitory transmitters modulate spontaneous transmitter release at cultured Aplysia sensorimotor synapses. J Physiol (Lond) 421:203-222.

Delaney KR, 7ucker RS (1990) Calcium released hy photolysis of DM-nitrophen stimulates transmitter release at squid giant synapse. J Physiol (Lond) 426:473-498.

Fernandez JM, Neher E, Gomperts BD (1984) Capacitance measurements reveal stepwise fusion events in degranulating mast cells. Nature 312:453-455.

Gerschenfeld HM, Hammond C, Paupardin-Tritsch D (1986) Modulation of the calcium current of molluscan neurones by neurotransmitters. J Exp Biol 124:73-91.

Gingrich KJ, Byrne JH (1985) Simulation of synaptic depression, posttetanic potentiation, and presynaptic facilitation of synaptic potentials from sensory neurons mediating gill-withdrawal reflex in Aplysia. J Neurophysiol 53:652-669.

Gomperts BD (1990) $\mathrm{G}_{\mathrm{E}}$ : a GTP-binding protein mediating exocytosis. Annu Rev Physiol 52:591-606.

Grynkiewicz G, Pionie M, Tsien RY (1985) A new generation of $\mathrm{Ca}^{2+}$ indicators with greatly improved fluorescence properties. J Biol Chem 260:3440-3450.

Hackett JT, Cochran SL, Greenfield LJ Jr, Brosius DC, Ueda T (1990) Synapsin I injected presynaptically into goldfish Mauthner axons reduces quantal synaptic transmission. J Neurophysiol 63:701-706.

Hawkins RD, Abrams TW, Carew TJ, Kandel ER (1983) A cellular mechanism of classical conditioning in Aplysia: activity-dependent amplication of presynaptic facilitation. Science 219:400-405.

Haydon PG (1988) The formation of chemical synapses between cellcultured neuronal somata. J Neurosci 8:1032-1038.

Haydon PG, Man-Son-Hing H (1988) Low- and high-voltage-activated calcium currents: their relationship to the site of neurotransmitter release in an identified neuron of Helisoma. Neuron 1:919927.

Haydon PG, Zoran MJ (1991) Chemical synapses in cell culture. In: Cellular neurobiology: a practical approach (Chad J, Whcal H, cds), in press. New York: Oxford UP.

Haydon PG, Cohan CS, McCobb DP, Miller HR, Kater SB (1985) Neuron-specific growth cone properties as seen in identified neurons of Helisoma. J Neurosci Res 13:135-147.

Haydon PG, Doyle RT, Man-Son-Hing HJ (1990) FMRFamide modulation of secretory machinery is mediated by a pertussis toxin sensitive $G$ protein. Soc Neurosci Abstr 16:167.

Hess SD, Augustine GJ (1990) Presynaptic inhibition induced by G protein activation at the squid giant synapse. Soc Neurosci Abstr 16: 1013.

Hochner B, Klein M, Schacher S, Kandel ER (1986) Additional component in the cellular mechanism of presynaptic facilitation contributes to behavioral dishabituation in Aplysia. Proc Natl Acad Sci USA 83:8794-8798

Ichinose M, Endo S, Byrne JH (1990) Role of protein phosphatases in FMRFamide, serotonin, and cAMP-dependent modulation of membrane currents in sensory neurons of Aplysia. Soc Neurosci Abstr 16:187.

Jones PM, Fryles JM, Persaud SJ, Howell SL (1987) Catecholamine inhibition of $\mathrm{Ca}^{2+}$-induced insulin secretion from electrically permeabilised islets of Langerhans. FEBS Lett 219:139-144.

Kandel ER, Schwartz JH (1982) Molecular biology of learning: modulation of transmitter release. Science 218:433-443.

Kandel ER, Schacher S, Castellucci VF, Goelet P (1986) The long and short of memory in Aplysia: a molecular perspective. In: Fidia research foundation neuroscience award lectures, pp 7-47. Padova: Liviana.
Kao JP, Harootunian AT, Tsien RY (1989) Photochemically generated cytosolic calcium pulses and their detection by fluo-3. J Biol Chem 264:8179-8184.

Kaplan JH, Ellis-Davies GCR (1988) Photolabile chelators for rapid photolytic release of divalent cations. Proc Natl Acad Sci USA 85: 6571-6575.

Knight DE, Baker PF (1985) Guanine nucleotides and Ca-dependent exocytosis: studies on two adrenal cell preparations. FEBS Lett 189 345-349.

Lipscombe D, Kongsamut S, Tsien RW (1989) $\beta$-Adrenergic inhibition of sympathetic neurotransmitter release mediated by modulation of N-type calcium-channel gating. Nature 340:639-642.

Llinas R, McGuiness TL, Leonard CS, Sugimori M, Greengard P (1985) Intraterminal injection of synapsin I or calcium-calmodulin-dependent protein kinase II alters neurotransmitter release at the squid giant synapse. Proc Natl Acad Sci USA 82:3035-3039.

Malenka RC, Ayoub GS, Nicoll RA (1987) Phorbol esters enhance transmitter release in rat hippocampal sliccs. Brain Res 403:198-203.

Man-Son-Hing H, Zoran MJ, Lukowiak K, Haydon PG (1989) A neuromodulator of synaptic transmission acts on the secretory apparatus as well as on ion channels. Nature 341:237-239.

Man-Son-Hing HJ, Haydon PG (1990) FMRFamide modulation of action potential-evoked synaptic transmission is mediated by a pertussis toxin-sensitive $G$ protein. Soc Neurosci Abstr 16:167.

McGuiness TL, Brady ST, Gruner JA, Sugimori M, Llinas R, Greengard $P$ (1989) Phosphorylation-dependent inhibition by synapsin I of organelle movement in squid axoplasm. J Neurosci 9:4138-4149.

Murphy AD, Lukowiak K, Stell WK (1985) Peptidergic modulation of patterned motor activity in identified neurons of Helisoma. Proc Natl Acad Sci USA 82:7140-7144.

Ngsee JK, Miller K, Wendland B, Scheller RH (1990) Multiple GTPbinding proteins from cholinergic synaptic vesicles. J Neurosci 10 317-322.

Oetting M, LeBoff M, Swiston L, Preston J, Brown E (1986) Guanine nucleotides are potent secretagogues in permeabilized parathyroid cells. FEBS Lett 208:99-104.

Pieroni JP, Byrne JH (1990) The mobilization process of facilitation produced by serotonin is inhibited by FMRFamide in sensory neurons of Aplysia. Soc Neurosci Abstr 16:596.

Piomelli D, Greengard P (1990) Lipoxygenase metabolites of arachidonic acid in neuronal transmembrane signalling. Trends Pharmacol Sci 11:367-373.

Piomelli D, Volterra A, Dale N, Siegelbaum SA, Kandel ER, Schwartz JH, Belardetti F (1987) Lipoxygenase metabolites of arachidonic acid as second messengers for presynaptic inhibition of Aplysia sensory cells. Nature 328:38-43.

Piomelli D, Wang JKT, Shira TS, Nairn AC, Czernik AJ, Greengard P (1989) Inhibition of $\mathrm{Ca}^{2+} /$ calmodulin-dependent protein kinase II by arachidonic acid and its metabolites. Proc Natl Acad Sci USA 86: 8550-8554.

Richmond JE, Funte LR, Smith LR, Price DA, Haydon PG (1991) Activation of a peptidergic synapse locally modulates postsynaptic calcium influx. J Exp Biol, in press.

Silinsky EM (1984) On the mechanism by which adenosine receptor activation inhibits the release of acetylcholine from motor nerve endings. J Physiol (Lond) 346:243-256.

Singh YN, Dryden WF, Chen H (1986) The inhibitory effects of some adenosine analogues on transmitter release at the mammalian neuromuscular junction. Can J Physiol Pharmacol 64:1446-1450.

Ullrich S, Wollheim CB (1988) GTP-dependent inhibition of insulin secretion by epinephrine in permeabilized RINm5F cells, lack of correlation between insulin secretion and cyclic AMP levels. J Biol Chem 263:8615-8620.

Wong RG, Hadley RD, Kater SB, Hauser GC (1981) Neurite outgrowth in molluscan organ and cell cultures: the role of conditioning factor(s). J Neurosci 1:1008-1021.

Zoran MI, Doyle RT, Haydon PG (1991) Target contact regulates the calcium responsiveness of the secretory machinery during synaptogenesis. Neuron 6:1-10.

Zucker RS, Haydon PG (1988) Membrane potential has no direct rolc in evoking neurotransmitter release. Nature 335:360-362. 